\title{
Varietal Evaluation of Asiatic Carrot for Yield, Yield Contributing Characters and Economics
}

\author{
Munish Sharma ${ }^{1 *}$, Yashwant Singh ${ }^{1}$ and P. Suryavanshi ${ }^{2}$ \\ ${ }^{1}$ Krishi Vigyan Kendra, S.A.S. Nagar (Mohali), \\ Guru Angad Dev Veterinary and Animal Sciences University, Ludhiana, Punjab, India \\ ${ }^{2}$ CSIR-Cental Institute of Medicinal \& Aromatic Plants-Lucknow, India \\ *Corresponding author
}

\section{A B S T R A C T}

\begin{tabular}{|l|}
\hline K e y w o r d s \\
Carrot, Varietal \\
Evaluation, Yield, \\
BC Ratio, \\
Economics \\
\hline Article Info \\
\hline $\begin{array}{l}\text { Accepted: } \\
10 \text { July } 2020 \\
\text { Available Online: } \\
10 \text { August } 2020\end{array}$ \\
\hline
\end{tabular}

Carrot (Daucus carota L.) is cool season crop and grown for its edible roots which are nutritionally rich in beta carotene, anthocyanins and minerals. It is used as salad, cooked vegetable and in juices. Per capita per day consumption of vegetables in India in general is quite low which is one of the major reasons behind malnutrition and vitamin-mineral deficiencies. District Mohali of Punjab falls under sub-mountainous zone where many farmers grow vegetables during rabi season and fetch remunerative returns. However it was observed that availability of high yielding carrot varieties along with high consumer preference is lacking. Hence, the present investigation was planned and carried out to find the suitable carrot variety for high root yield, better quality and good returns in Mohali district of Punjab. The present investigation was carried out in five farmer's field during rabi 2019-20 to evaluate three genotypes of carrot for root yield and contributing characters. From the results of the On Farm Trial conducted, it was revealed that $\mathrm{T}_{1}$ (Farmer's practice) gave root yield of $400 \mathrm{Q} /$ ha whereas $\mathrm{T}_{2}$ (Punjab Black Beauty) gave $450 \mathrm{Q} / \mathrm{ha}$ and $\mathrm{T}_{3}$ (PC-161) gave $575 \mathrm{Q} / \mathrm{ha}$. Thus PC-161 yielded maximum i.e 575(Q/ha) along with the maximum $\mathrm{B}$ : $\mathrm{C}$ ratio $(3.87: 1)$ as compared to Punjab Black Beauty i.e 3.05:1 and farmers practice with $\mathrm{B}: \mathrm{C}$ ratio of 2.78:1.

\section{Introduction}

Carrot (Daucus carota L.) is a cool season crop grown all over the globe as the edible part of the crop is characterized by its high beta carotene content, a precursor of vitamin $\mathrm{A}$ and act as an excellent source of iron, calcium, phosphorus, vitamin B, sugar and folic acid (Rahman et al. 2018). Carrot cultivars are broadly classified in two groups viz. Asiatic or Oriental types and European or Temperate types. In India, Carrot cultivars which are grown in Punjab, U.P, Andhra Pradesh, Karnataka, Assam and Haryana belongs to Asiatic group (Ladumor et al. 2020). The Asiatic carrots are generally red coloured because of anthocyanin pigment. The consumption of vegetables per capita per day in India is $135 \mathrm{~g}$ against the requirement of $300 \mathrm{~g}$ per capita per day. Carrot requires 
comparatively longer growing season than other root crops. Area under vegetable cultivation and production is quite less in Punjab as compared to other crops. Many farmers of S.A.S. Nagar (Mohali) district of Punjab grow vegetable crops during rabi season and fetch good prices. However, carrot cultivation is now gaining popularity among farmers in Punjab. The reason for low productivity of carrot is lack of suitable varieties and their adoption by the farmers. It indicates the necessity to raise the production of vegetables which can be achieved by bringing more area under vegetable cultivation and increasing the productivity as well. Crop diversification is also the need of the hour and it can be achieved through promotion of vegetable cultivation. Carrot is comparatively easy to grow crop and due to its high nutritional value its demand is quite high in the market. But farmers of the district are not much aware about the suitable carrot varieties. There are several factors like variety, time of sowing, nutrition management and irrigation which play a major role in yield and quality production. Among these factors variety plays a predominant role in quality yield production. No systematic study has been conducted to assess the suitability of carrot cultivation in Mohali district, for which standardization of varieties is of immense utility. Hence evaluation of high yielding carrot varieties with good quality is of great importance to enhance the productivity of the crop. Therefore, the present investigation was carried out to find the better variety of carrot in terms of yield and quality along with its cost of cultivation and benefit cost ratio for Mohali district of Punjab.

\section{Materials and Methods}

\section{Experimental site, treatments and design}

District Mohali of Punjab falls under submountainous zone $\left(30.69^{\circ} \mathrm{N}\right.$ latitude, $76.72^{\circ} \mathrm{E}$ longitude) having an average altitude of 316 $m$ from the sea level. The present investigation was carried out in five farmer's field during 2019-20 to evaluate three genotypes of carrot in farmer's field for root yield and component traits. The area under each trial was one acre. The soil of the experimental site was deep, loose and sandy loam. The trial was conducted in randomized block design (RBD) with three replications. The treatments included: $\mathrm{T}_{1}$ : Farmers Practice or FP, $\mathrm{T}_{2}$ : Black Beauty \& $\mathrm{T}_{3}$ : PC-161. The Weather data of the experimental site was given in Table 1 for the growing period of the crop.

The land was brought to a fine tilth by repeated ploughing and harrowing. The clods were broken and debris was removed. The soil was levelled and raised beds were prepared. For cultivation of crop, recommended package of practices were followed. The seeds were sown during the month of September. $5 \mathrm{Kg}$ seed per acre was used. The seeds were sown at a spacing of 45 $\mathrm{cm}$ between ridges $\times 7.5 \mathrm{~cm}$ between plants. The plant spacing is maintained by manual thinning at the time of true leaf formation. Before fertilizer application, random soil samples were taken from the experimental site and were analyzed. 15 tonnes of well rotten farmyard manure, $55 \mathrm{~kg}$ of urea, $75 \mathrm{~kg}$ of single superphosphate and $50 \mathrm{~kg}$ of muriate of potash was applied in one acre area. All the fertilizers were applied at the time of sowing. 2-3 hoeings were done for weed control. One weeding followed by earthing up about 4-5 weeks after sowing was done. 3-4 irrigations were given to crop including one immediately after sowing. The crop was harvested when roots developed desirable marketable size and colour.

\section{Data collection}

Five plants were selected at random from each plot for recording observations like plant length $(\mathrm{cm})$, root length $(\mathrm{cm})$, leaf length $(\mathrm{cm})$ 
and root girth $(\mathrm{cm})$. Days taken for harvest were calculated as days from sowing to first harvest. Based on the net plot yield, root yield per hectare was calculated and expressed in quintal (Q) per hectare. \% increase was calculated as: $\%$ increase $=($ Increase $/$ original number) $\times 100$.

\section{Economic analysis}

The cost of cultivation and gross returns were worked out by using prevailing market prices of inputs during the period of investigation. Labour and power cost for different operations such as ploughing, weeding, irrigation, sowing, bed preparation and harvesting etc. along with inputs such as seed and fertilizers were considered as per market price. Net returns were worked out using formula: Net Returns (Rs/ha) $=$ Gross Returns (Rs/ha)-Cost of cultivation (Rs/ha). Benefitcost ratio (BCR) was worked out by using the following formula. Benefit: Cost ratio (BCR) $=$ Gross return $(\mathrm{Rs} / \mathrm{ha}) /$ Total cost of cultivation (Rs/ha).

Statistical analysis was done using standard procedure given by Panse and Sukhatme (1985).

\section{Results and Discussion}

Root yield and yield contributing characters

From the results of the investigation conducted (Table 2), it was revealed that $T_{1}$ gave $400 \mathrm{Q} /$ ha yield whereas $\mathrm{T}_{2}$ gave 450 $\mathrm{Q} /$ ha and $\mathrm{T}_{3}$ gave $575 \mathrm{Q} / \mathrm{ha}$. The data of the trial revealed that $T_{3}$ gave maximum yield of carrot $575(\mathrm{Q} / \mathrm{ha})$ along with the maximum $\mathrm{B}$ : $\mathrm{C}$ ratio (3.87:1) compared to $\mathrm{T}_{2}$ i.e 3.05:1 and $\mathrm{T}_{1}$ (farmers practice) with $\mathrm{B}$ : $\mathrm{C}$ ratio of 2.78:1. The higher yield of PC-161 was primarily attributed due to more plant, root and leaf length. It was observed that \% increase over check was found to be maximum for PC-161 i.e: 43.75 followed by Punjab Black Beauty i.e 12.50. It was noticed that, the genotypes which performed better in a unit area were likely to perform better on large scale as the yield per hectare was calculated by multiplying yield per plot with hectare factor. The yield is the result of interaction of the variety to a given agro climatic condition and various management factors. These results are in conformity with those of Verma \& Gupta (2005), Kazerani and Salajegheh (2009), Akter and Islam (2011) and Mishra et al. 2018.

The variety selected under farmer's practice took ninety two days for first harvest whereas Punjab Black Beauty took 96 days and PC161 took minimum 88 days. Highest plant length was recorded in PC-161 $(64 \mathrm{~cm})$ followed by Punjab Black Beauty $(60 \mathrm{~cm})$ and Farmer's practice $(56 \mathrm{~cm})$. The results are in close proximity with the findings of Rajan and Markos (2008) and Malek et al. 2012 in which he studied the effect of varieties on plant height of carrot. This might be due to genetic phenomenon of these varieties.

Table.1 Weather Data of the district in growing season of crop

\begin{tabular}{|l|c|c|c|}
\hline Month & Temp (Max) & Temp (Min) & Average Rainfall (mm) \\
\hline September 2019 & 33.8 & 22.9 & 4.23 \\
\hline October 2019 & 30.9 & 18.7 & 0.0 \\
\hline November 2019 & 26.2 & 13.5 & 1.3 \\
\hline December 2019 & 17.4 & 8.4 & 44.9 \\
\hline January 2020 & 17.9 & 8.0 & 2.10 \\
\hline
\end{tabular}


Table.2 Mean performance of different carrot varieties for root yield and growth traits

\begin{tabular}{|l|l|l|l|l|l|l|l|}
\hline $\begin{array}{l}\text { Treatments/ } \\
\text { Observations } \\
\text { recorded }\end{array}$ & $\begin{array}{l}\text { Days } \\
\text { taken for } \\
\text { harvest }\end{array}$ & $\begin{array}{l}\text { Plant } \\
\text { length } \\
\text { (cm) }\end{array}$ & $\begin{array}{l}\text { Root } \\
\text { length } \\
\text { (cm) }\end{array}$ & $\begin{array}{l}\text { Leaf } \\
\text { length } \\
\text { (cm) }\end{array}$ & $\begin{array}{l}\text { Root } \\
\text { girth } \\
\text { (cm) }\end{array}$ & $\begin{array}{l}\text { Root } \\
\text { yield } \\
\text { (q/ha) }\end{array}$ & $\begin{array}{l}\text { \% increase } \\
\text { over check }\end{array}$ \\
\hline T1 & 92 & 56 & 24 & 32 & 2.92 & 400 & \\
\hline T2 & 96 & 60 & 26 & 34 & 3.10 & 450 & 12.50 \\
\hline T3 & 88 & 64 & 28 & 36 & 2.82 & 575 & 43.75 \\
\hline S E(m) & 1.33 & 1.76 & 2.52 & 1.00 & 0.05 & 8.33 & \\
\hline CD@0.05 & 5.38 & NA & NA & NA & 0.19 & 33.60 & \\
\hline
\end{tabular}

Table.3 Economic returns from different varieties of Carrot

\begin{tabular}{|l|c|l|c|c|}
\hline $\begin{array}{l}\text { Treatments/Observations } \\
\text { recorded }\end{array}$ & $\begin{array}{l}\text { Cost of } \\
\text { cultivation } \\
\text { (Rs/ha) }\end{array}$ & $\begin{array}{l}\text { Gross } \\
\text { Return } \\
\text { (Rs/ha) }\end{array}$ & $\begin{array}{l}\text { Net return } \\
\text { (Rs/ha) }\end{array}$ & B:C ratio \\
\hline T1 & $1,43,750$ & $4,00,000$ & $2,56,250$ & 2.78 \\
\hline T2 & $1,47,500$ & $4,50,000$ & $3,02,500$ & 3.05 \\
\hline T3 & $1,48,750$ & $5,75,000$ & $4,26,250$ & 3.87 \\
\hline
\end{tabular}

Fig.1 Economic returns of carrot varieties

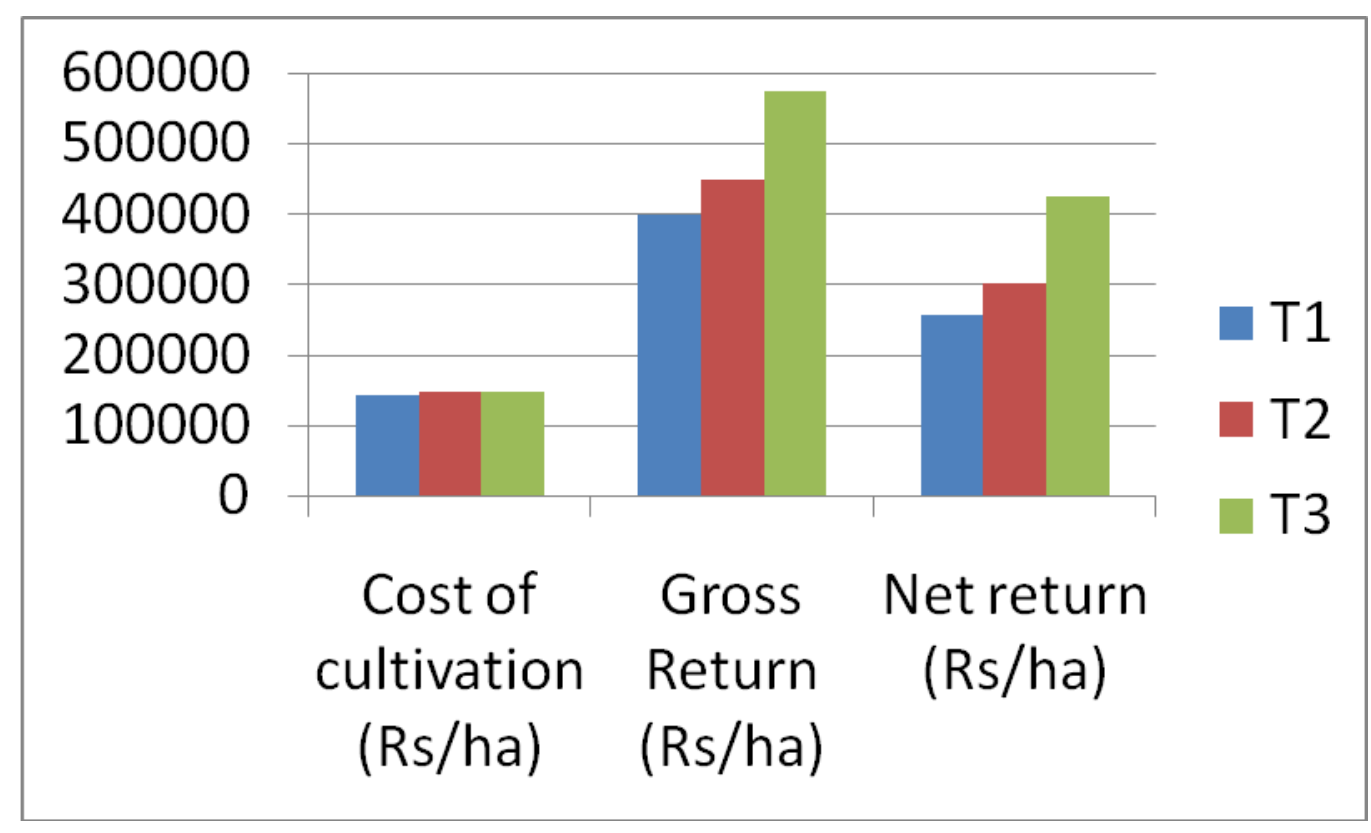

The augmentation in plant height is the result of intensive cell division and cell enlargement which in turn is influenced by protein synthesis. Therefore any variation in cell metabolism can consequently affect the plant height (Sharma et al. 2016). Maximum root length was recorded in PC-161 $(28 \mathrm{~cm})$ followed by Punjab Black Beauty $(26 \mathrm{~cm})$ and Farmer's practice $(24 \mathrm{~cm})$. Similar trends were also observed for leaf length which is an important growth character. In PC-161 maximum leaf length of $36 \mathrm{~cm}$ was recorded 
followed by Punjab Black Beauty $(34 \mathrm{~cm})$ and Farmer's practice $(32 \mathrm{~cm})$. Root girth is another important trait. Punjab Black Beauty was found to be having maximum root girth of $3.10 \mathrm{~cm}$ followed by FP $(2.92 \mathrm{~cm})$ and PC$161(2.82 \mathrm{~cm})$. Such variations among varieties could also be attributed to genetic background of varieties which bears a strong influence on the growth potential of plant. Similar findings were reported by Sharma et al. 2016 and Sharma et al. 2018. According to the opinion of Karklelien (2008), the desirable carrot from the view point of its demand, should have root length about $18-22 \mathrm{~cm}$ and root diameter about $3.6-4.1 \mathrm{~cm}$.

\section{Economics}

The economic analysis describes the methods used in analyzing the economic behaviour and the application of the results obtained to solve the economic problems. The input and output prices of commodities prevailed during the year of demonstration were taken for calculating cost of cultivation, net returns and benefit cost ratio. Net profit /ha also depends upon the availability of labour and a suitable market for the disposal of produce. Results of the present investigation (Table 3 ) revealed that $\mathrm{T}_{1}$ gave net return of Rs. $2,56,250 /$ ha with $B$ : $C$ ratio of 2.78:1 whereas $T_{2}$ gave net return of Rs. 3,02,500/ha with $\mathrm{B}$ : $\mathrm{C}$ ratio of 3.05:1 and $\mathrm{T}_{3}$ gave net return of Rs. $4,26,250 /-$ with $\mathrm{B}: \mathrm{C}$ ratio of $3.87: 1$. The total cost of production was maximum for PC-161 (Rs. 1, 48,750/-) followed by Punjab Black Beauty (Rs.1, 47,500/-) and Farmer's practice (Rs. 1, 43,750/-). Gross return was found to be maximum for PC-161 Rs. 5,75,000/followed by Punjab Black Beauty (Rs. 4,50,000/-) and Farmer's practice (Rs. $4,00,000 /-)$. The results are in line with results of Kale 2002, Singh and Bankar 2006, Verma 2007 and Singh et al. 2007 who also studied economics of vegetable cultivation. Similar studies were also carried out by Sharma et al.
2018 in carrot and Parmar et al. 2018 who made an economic evaluation of tomato.

From the results of present investigation it was concluded that adoption of carrot variety PC-161 is most suitable for cultivation in Mohali district of Punjab as it gave highest yield along with highest returns per unit area as compared to the other varieties being grown by the farmers in the district. The overall performance of PC-161 was superior to other varieties and found most suitable for cultivation in the district. Higher yield, long sized roots and earliness are some of the characters which might be responsible for increase in profit of carrot growing farmers. In addition to this market acceptability and consumer preference of this variety is quite satisfactory.

\section{Acknowledgements}

The authors are highly thankful to the ICARATARI Zone-1, Ludhiana for providing funds to conduct this experiment.

\section{References}

Akter, S., and Islam, MS. 2011. An economic analysis of winter vegetable production in some selected areas of Narsingdi district. Journal of Bangladesh Agriculture University. 9(2): 241-246.

Kale, VC. (2002). Economics of selected vegetables in vicinity of Parbhani city. Report submitted to AGRESCO Social science sum committee. pp 11-16.

Karkleliene, R. (2008). Evaluation of the morphological, physiological and biochemical parameters of edible carrot (Daucus sativus Röhl.). Biologia. 54(2), 101-104.

Kazerani, N., \& Salajegheh, F. (2009). Evaluation of quantitative and qualitative traits, carrots, tomatoes digits in the province Bushehr Research 
Center for Agriculture and Natural Resources. 8 pages.

Ladumor, RG., Nandre, BM., Sharma, MK., Wankhade, VR., and Joshi, PC. 2020. Performance of different varieties of carrot (Daucus carota L.) with respect yield, quality and chemical compositions under varying sowing times. International Journal of Current Microbiology and Applied Sciences. 9(2): 126-132.

Malek, MA., Mohammed, D., Sikdar, M., and Rahman, MS. 2012. Effects of variety and growing condition on yield and quality of carrot seed. Journal of Environ. Sci. and Natural Resources. 5(2): 301-306.

Mishra, G., Nanda, SS., and Bairagya, MD. 2018. Studies on yield and economics of winter vegetables in North East Ghat Zone of Odisha, India. International Journal of Current Microbiology and Applied Sciences. 7(8):3869-3873.

Panse, VG., and Sukhatme, PU. (1985).Statistical Methods for Agricultural Workers, Indian Council of Agriculture Research, New Delhi.

Parmar, DK., Thakur, DR., Jamwal, RS., and Singh, Gurudev. 2018. Evaluation of tomato cultivars for yield, profit and quality performance in an organic management system in North Western Himalayas, India. International Journal of Current Microbiology and Applied Sciences. 7(10): 498-506.

Rahman, Atikur, Md., Md, Tariqul, Islam., M Abdullah, Al Mamun., Mohammad, Shahidur, Rahman., and Most, Sarmin, Ashraf. 2018. Yield and quality performance of carrot under different organic and inorganic nutrient sources with mulching options. Asian Journal of Agricultural and Horticultural Research. 1(4):1-8.

Rajan, and Markos, B. (2008). Propagation of horticultural crops. New India Publishing Agency. New Delhi. 255 p.

Sharma, Munish., and Singh, Yashwant. 2018. Comparative evaluation of carrot varieties in district Mohali of Punjab. Journal of Krishi Vigyan. 7(1): 220222.

Sharma, Samir., Dhami, Vandana., Tyagi, Manu., \& Singh, CP. 2016. Morphological evaluation of Radish (Raphanus Sativus L.) varieties in foothill conditions of Uttarakhand. International Journal of Agricultural Sciences. 8(63): 3591-3593.

Singh, AK., and Bankar, KN. (2006). An economic analysis of production and marketing of cauliflower in Durg district of Chhatisgarh State. Ind. J. of Agric. Mrkg. 59(3):37-42.

Singh, RK., Singh, RA., and Mishra, JP. (2007). Economic study on production and marketing of hybrid tomato in Ghazipur district of Uttar Pradesh. Ind. J. of Agric. Mrkg. 50(3):32-36.

Verma, AR. (2007). Economics of production, resource use efficiency, marketing and constraints of potato in Indore district of Madhya Pradesh. Ind. J. of Agric. Mrkg. 50(3):21-30.

Verma, TS., \& Gupta, A. (2005). Performance of temperate carrot genotypes including $\mathrm{F}_{1}$ hybrids and varieties in multi location trials. Ind. J. of Agric Sci. 75(5):298-300.

\section{How to cite this article:}

Munish Sharma, Yashwant Singh and Suryavanshi, P. 2020. Varietal Evaluation of Asiatic Carrot for Yield, Yield Contributing Characters and Economics. Int.J.Curr.Microbiol.App.Sci. 9(08): 443-448. doi: https://doi.org/10.20546/ijcmas.2020.908.052 